\title{
CHRISTIANITY AND JUDAISM—CONSULTATION
}

Topic: $\quad$ Theology in the World After Auschwitz? The Quest of Johann Baptist Metz and the Scholarship of John Pawlikowski

Convener: Carol Ann Martinelli, Independent Scholar

Moderator: Mary Doak, University of San Diego

Presenter: Julia Prinz, V.D.M.F., Jesuit School of Theology of Santa Clara University

Jewish Respondent: Russell C. D. Arnold, Regis University

Catholic Respondent: Kevin F. Burke, S.J., Regis University

Julia Prinz's paper, "Facing the Jews: Biblical Spirituality as Fount of Metz's Political Theology," explores the ground-breaking work of the eminent German theologian, Johann Baptist Metz, by asking how Metz reads biblical text after Auschwitz and determining his hermeneutical entry point into the theological task. Drawing from this and in response to the Enlightenment critique of authority, Metz upholds what he calls "the authority of those who suffer" and who thereby provoke "unreconciled and open questions." This hermeneutical perspective provides a crucial intellectual and existential grounding for all of theology, a point that Prinz emphasized with reference to Metz's own experiences during the Nazi regime.

Metz develops a theology bound to the specific terrain of Auschwitz and to the concrete individual human beings who suffered and died there. From this perspective Metz was confronted with the question of the cognitive process of theological knowing. Metz's challenge is to perceive Auschwitz as an inherent theological question that cannot be separated from the historical social setting. Metz developed the category of memory as the decisive religious category. Metz's theological hermeneutics of memory was inspired by commentary from Walter Benjamin on a Paul Klee painting named "Angelus Novus"- an angel viewing a catastrophe of wreckage upon wreckage behind him, as the angel is propelled into the future. Following Benjamin, Metz understood that memory is a powerful source of resistance and is deepened when speaking of "dangerous memory"-memory that faces the catastrophe. Metz would say that memories of suffering hold the content for the future. To remember the dying is resistance against moving on as before. According to Metz, if faith is understandable by reason it must be an anamnestic reason, a reason endowed with memory. This reason, memory of suffering and memory of what is missing due to loss of life and suffering, as the central form of knowledge, shifts paradigms. Metz's "knowledge of what is missing" [Vermissungswissen] is not only an authentic religious consciousness, but also gives rise to a knowledge of freedom and a sense of justice.

Metz's argument is profoundly biblical and profoundly anti-Fascist. Prinz notes that even his early book, Poverty of Spirit, is often misread as a merely pious book penned for religious novices; in fact, it serves as a scathing critique of Nazi anthropology. Similarly, the hermeneutic of danger that Prinz developed from Metz's use of the biblical text reveals how his focus on narrative and memory pierces "strong" Aristotelian categories with the "weakness" of human experience. Metz developed his theological paradigm shift calling his theological categories "weak" because they draw the weak and suffering into the center of theological attention rather than the victors and the strong. This point appears starkly in the texts of Lamentations and Job, which pierce affirmative theological speech and bring questions of suffering and theodicy to 
the surface. In the hermeneutic of danger, the process of textual interpretation endangers the same person who engages in memory. Prinz acknowledges that "theology in the world after Auschwitz?" is not given a definitive answer by Metz, but rather serves to question any theology caught in self-affirming philosophical categories. Metz reclaimed biblical retelling of memory and narratives as foundational theological categories and strengthened them by the authority of experience and biography.

Russ Arnold responded to Prinz's paper, "as a Jew facing Christians who are facing Jews," posing questions as to Metz's proposals from the perspective of Bible and memory. What is meant by reading the Bible for Metz's "knowledge of what is missing"? It is Midrash at its heart. Laasoq bdivrei torah-what God commands is engagement to enter into and wrestle with the stories. Is the Bible a history of the vanquished? What is its relationship to structures of power/victory? Jews read the Bible as their own story of the vanquished, but erasure of the vanquished is not completecompeting conceptions of God, permissibility of dreams as communications from God, conceptions of holiness, etc. Midrash tries to keep the consciousness of the vanquished. Every liberation is tempered by ongoing vulnerability and short-term victory. Memories of liberation (Pesach) are commemorated as incomplete, as past victories needing to be re-won. "What is missing" is sought, questions multiplied. How is memory a biblical category? The call to remember is understood in various ways in the Torah as in Exodus and Deuteronomy. How do Jews today relate to Metz's idea of dangerous memory? Memory of Auschwitz is dangerous for Jews and Christians for different reasons and fraught with political implications. Holocaust remembrance, a memory of Jewish suffering, has become for many Jews, a strong category built on victimization. This remembrance can serve as an expression of power among Jews and can shield from the reflection called for by Metz. Prinz's hermeneutic of danger, danger retold in the biblical narrative, however, calls to resistance and change of political status quo.

Kevin Burke's response took the form of a series of observations regarding Metz's theology and Prinz's interpretation of Metz. Echoing Prinz, he argued that without "facing the Jews" we can fall into the illusion that nothing has changed after "Auschwitz," which Metz's theology regards as a theological term. The historicaltheological significance of Auschwitz is often in need of defense based on a forgetfulness of suffering. Dangerous memory breaks through ruling structures and takes on a subversive character and holds a future content. Burke then highlighted the distinctiveness of Prinz's hermeneutic of danger and her account of the biblical spirituality underlying Metz's political theology. Based on Prinz's work Burke compared Metz's political theology and that of Gustavo Gutiérrez, pointing out that in neither is suffering abstract, nor is it "located in" God. Metz places suffering at the center of theology by adopting the weak, practical theological categories of memory, narrative, solidarity, and lament. He finally observed that today's crisis of (growing indifference to) religion is a crisis of God. Metz's recognition of a dangerous theological tendency to "encipher" God-talk with church-talk plays a central role in the crisis as God is confused with thoughts about God. 
The session concluded with energetic group discussion followed by the Consultation's celebration of the decades of unprecedented scholarship in the field of Jewish Christian relations by the American theologian, John Pawlikowski, a founder of this Consultation. A special presentation was made to him by Mary Doak and Elena Procario-Foley. John was honored with a beautifully framed print of Righting Relations After the Holocaust and Vatican II, Essays in Honor of John Pawlikowski, OSM, a 2018 festschrift recognizing his countless contributions over many years devoted to theological developments in the field of Jewish Christian studies.

CAROL ANN MARTINELLI Independent Scholar Detroit, Michigan 